\title{
The Cells of the Vitreous Body
}

\begin{tabular}{|l|l|}
\hline J.A. & \\
\hline E.A. & Szirmay $^{\mathrm{a}}$ \\
\hline
\end{tabular}

aLeyden, ${ }^{\mathrm{b}}$ Boston

(To be published in the Archives of Ophthalmology, Chicago.)

Discussion.

Hamburg asked the following questions:

I have studied the distribution of the cells of the vitreous body over its surface in the bovine eye, and found that it was fairly regular, i.e. there were no more at the anterior than at the posterior aspect. The greatest accumulation of cells was found between the ciliary processes. How does that agree with the fact that the greatest concentration of hyaluronic acid is found in the posterior part of the vitreous body?

The density of the cells at the surface of the vitreous body varies widely in the different animal species; in cattle it is approximately 300 per sq.mm., in the pig it is about the same, but in the cat less and in rabbits still less, viz., 25 per sq.mm. according to Schwalbe. However, in rats, with a very small vitreous body, the cellular density was greater, viz., 80 to 100 per sq.mm., so that in this latter case an extremely high hyaluronidase content should be expected. Is something known about a possible relationship between the number of cells at the surface of the vitreous body and the quantity of hyaluronic acid in the vitreous? Or are there indications that the cellular activities among the different animals differ?

Some of my studies which are not yet fit for publication make it appear possible that the cells of the vitreous body have properties in common with the migratory cells. Renaut in 1904 described cells

which he called rhagio-crine cells

thus indicating that he attributed a secretory function to them

in connection with the fact that these cells

when stained red with supravital staining

showed a number of red granules. Later

these cells proved to be identical with histiocytes. The presence of granules in the cells of the vitreous

which also stain with neutral red

is certainly no evidence against a histiocytic character. On the other hand it is not implied that histiocytes cannot produce hvaluronic acid. 